\title{
EFFECT OF THE INGESTION OF THE PALM OIL AND GLUTAMINE IN SERUM LEVELS OF GLP-1, PYY AND GLYCEMIA IN DIABETES MELLITUS TYPE 2 PATIENTS SUBMITTED TO METABOLIC SURGERY
}

\author{
Efeito do óleo de palma e da glutamina nos níveis séricos de GLP-1, PYY e da glicemia em portadores de diabete melito tipo 2 \\ submetidos à cirurgia metabólica
}

Tharsus Dias TAKEUTI, Guilherme Azevedo TERRA, Alex Augusto da SILVA,
Júverson Alves TERRA-JÚNIOR, Luci Mara da SILVA, Eduardo CREMA

From the Universidade Federal do Triângulo Mineiro (Federal University of Triângulo Mineiro), Uberaba, MG, Brazil.

HEADINGS - Diabetes Mellitus. Palm oil. Glutamine.
ABSTRACT - Background: Incretins are hormones produced by the intestine and can stimulate the secretion of insulin, helping to diminish the post-prandial glycemia. The administration of an emulsion of palm oil can help in the maintenance of the weight, and can increase circulating incretins levels. Glutamine increases the concentration of incretins in diabetic people. Both can help in metabolic syndrome. Aim: To analyze the effects of ingestion of palm oil and glutamine in glycemia and in incretins in patients with diabetes submitted to surgical duodenojejunal exclusion with ileal interposition without gastrectomy. Methods: Eleven diabetic type 2 patients were included and were operated. They were called to laboratory follow-up without eating anything between eight and 12 hours. They had there blood collected after the stimulus of the palm oil and glutamine taken in different days. For the hormonal doses were used ELISA kits. Results: The glycemia showed a meaningful fall between the fast and two hours after the stimulus of the palm oil $(p=0,018)$. With the glutamine the GLP-1 showed an increase between the fast and one hour $(p=0,32)$, the PYY showed an important increase between the fast and one hour after the stimulus $(p=0,06)$, the glycemia showed a meaningful fall after two hours of the administration of the stimulus $(p=0,03)$. Conclusion: Palm oil and glutamine can influence intestinal peptides and glucose

\section{Correspondence: \\ Eduardo Crema \\ E-mail: cremauftm@mednet.com.br}

Financial source: Foundation for Research Support of the State of Minas

Gerais (FAPEMIG)

Conficts of interest: none

Received for publication: 11/03/2014 Accepted for publication: $26 / 06 / 2014$

DESCRITORES - Diabetes mellitus. Óleo de palmeira. Glutamina.
RESUMO - Racional: A administração de óleo de palma auxilia na manutenção do peso e aumenta níveis de incretinas circulantes. A glutamina aumenta a concentração de incretinas em indivíduos diabéticos. Assim, eles podem influenciar no tratamento da síndrome metabólica. Objetivo: Analisar os efeitos da ingestão de óleo de palma e glutamina na glicemia e incretinas em pacientes diabéticos que foram submetidos à operação de exclusão duodenojejunal com interposição ileal sem gastrectomia. Métodos: Participaram 11 pacientes, portadores de diabete melito tipo 2, que foram operados com exclusão duodenojejunal com interposição ileal sem gastrectomia. Foram convocados para comparecer ao laboratório em jejum de oito a 12 horas e submetidos ao procedimento de coleta de sangue após os estímulos de óleo de palma e glutamina via oral em dias distintos. Para as dosagens hormonais foram utilizados kits de ELISA. Resultados: A glicemia apresentou queda significativa entre o jejum e duas horas após o estímulo de óleo de palma $(p=0,018)$. Com a glutamina, o GLP-1 apresentou aumento entre o jejum e uma hora $(p=0,32)$; o PYY apresentou aumento entre o jejum e uma hora após o estímulo $(p=0,06)$; a glicemia apresentou queda significativa após duas horas da administração do estímulo $(p=0,03)$. Conclusão: $O$ óleo de palma e a glutamina podem influenciar os peptídeos intestinais e na glicemia.

\section{INTRODUCTION}

$\mathrm{T}$ ype 2 diabetes mellitus (T2DM) is a complex metabolic disorder whose clinical manifestations include hyperglycemia and its complications ${ }^{18}$.

The disease is characterized by resistance to insulin and progressive failure of beta cells ${ }^{11}$ and hyperglycemia plays an essential role in the development of diabetic complications ${ }^{3}$. About 285 million adults worldwide are estimated to have diabetes, $85 \%$ to $95 \%$ of them with $\mathrm{T}^{2} \mathrm{DM}^{19}$. Conventional methods of bariatric surgery and new gastrointestinal surgical techniques can cause long-term remission of diabetes and improve other metabolic disorders such as hyperlipidemia and hypertension in non-obese patients ${ }^{22}$.

Metabolic surgery is currently defined as any modification of the gastrointestinal tract in which the passage and rerouting of food permits the improvement of T2DM, irrespective of mechanisms of weight loss. Although not the standard treatment for T2DM, this surgical procedure has become close to ideal. Studies have shown that metabolic surgery is a reasonable alternative for diabetic patients with a body mass index $(\mathrm{BMI})<35 \mathrm{~kg} / \mathrm{m}^{2}$ who do not respond to standard therapy ${ }^{25}$.

The exclusion of the duodenum and part of jejunum alters food transit, leading to early arrival of undigested or partially digested food in the ileum which, in turn, causes changes in the secretion of gastrointestinal hormones ${ }^{21}$. 
Incretins are hormones produced by the intestine that stimulate the secretion of insulin and consequently reduce postprandial glycemia ${ }^{12}$. About two-thirds of the insulin response to oral glucose is the result of the potentiation of incretin action ${ }^{1}$. In normal subjects, insulin secretion is higher when glucose is ingested orally compared to the same load of intravenous glucose, an effect known as the incretin effect ${ }^{18}$. Incretins facilitate the uptake of glucose by the liver and simultaneously suppress the secretion of glucagon by pancreatic alpha-cells, thus reducing endogenous glucose production in the liver ${ }^{8}$. The main incretins are gastric inhibitory polypeptide (GIP), also known as glucose-dependent insulinotropic polypeptide, and glucagon-like peptide 1 (GLP-1). After the discovery of the actions of these hormones, advances occurred in the treatment of T2DM in terms of incretin-based glucoselowering medications ${ }^{4}$.

Peptides produced by the intestine also regulate appetite and food intake and, through their effect on the hypothalamus, can induce a sensation of satiety ${ }^{20}$. GLP-1 is a prohormone consisting of 160 amino acids, which is produced by L-cells of the distal intestine, alpha-cells of the pancreatic islets, and the central nervous system ${ }^{26}$. This hormone is secreted in response to the ingestion of nutrients, with glucose and triacylglycerols being the main components stimulating this hormone. However, fructose and other proteins can also induce the secretion of GLP-1 ${ }^{12}$.

Peptide YY (PYY) consists of a chain of 36 amino acids and is produced by L-cells of the enteroendocrine epithelium of the intestine. Increased concentrations of this hormone are observed in the distal parts of the intestine such as colon and rectum. PYY acts on distant target tissues and its various functions include the delay of gastric emptying ${ }^{10}$.

Palm oil is derived from the mesocarp of fruits of the palm tree Elaeis guineensis ${ }^{24}$. The oil contains a fraction rich in vitamin E and tocotrienol. The latter is a potent antioxidant that contributes to the treatment of diabetes by reducing oxidative stress resulting from hyperglycemia ${ }^{3}$. Diepvens et al. ${ }^{7}$ observed that the administration of an emulsion of fractionated palm oil (40\%) and fractional oat oil $(2.5 \%)$ in water contributes to weight maintenance, in addition to increasing circulating GLP-1 levels.

Glutamine is an $L-\alpha$-amino acid that can be synthesized by any tissue of the organism and is the most abundant free amino acid found in plasma, muscle and other body tissues. Glutamine is involved in cell proliferation and growth, particularly cells of the immune system. Other functions include regulation of the acid-base balance, transport of ammonia between tissues, and donation of carbon skeletons for glyconeogenesis ${ }^{6}$. Glutamine is a nutritional supplement that contributes to the maintenance of intestinal integrity. Oral administration of glutamine protects the intestine of patients undergoing chemoradiotherapy ${ }^{9}$. In addition, oral glutamine has been shown to increase the concentration of GLP-1 in lean, insulin-resistant, obese and diabetic patients ${ }^{23}$. Reimann ${ }^{15}$ showed that glutamine also stimulates the secretion of GIP in rat duodenal cell cultures

The objective of the present study was to evaluate the effects of ingestion of palm oil and glutamine on serum levels of GLP-1, PYY and glycemia in T2DM patients submitted to surgical duodenojejunal bypass with ileal interposition and without gastrectomy.

\section{METHODS}

The study was approved by the Ethics Committee of Universidade Federal do Triângulo Mineiro (Permit No. 1726). All patients signed a free informed consent form.
Eleven patients, five men (45.45\%) and six women (54.54\%), ranging in age from 21 to 60 years, participated in the study. All patients had T2DM, underwent surgery in 2010, and were followed up for 2 years. The values obtained for the patients served as their own control for descriptive analysis.

Patients fasted for a minimum period of $8 \mathrm{~h}$ and a maximum period of $12 \mathrm{~h}$ were invited for blood collection after oral ingestion of palm oil and glutamine on different days. On the first day, the patients ingested 9 $\mathrm{g}$ palm oil emulsion in encapsulated form to facilitate oral administration. On the second day, $30 \mathrm{~g}$ glutamine diluted in $200 \mathrm{ml}$ water was administered orally. Two patients did not appear on the second day and blood was therefore collected from only nine patients.

Three blood samples were collected from one of the arms through a venous access device, one in the fasted state and the second and third 1 and $2 \mathrm{~h}$ after the ingestion of palm oil or glutamine, respectively. During each collection, blood was collected into two vacuum tubes with a yellow cap containing separation gel. In one tube, $10 \mu$ l dipeptidyl peptidase inhibitor 4 diluted in $1 \mathrm{ml}$ blood was added to prevent the degradation of GLP-1 and PYY. The other tube was used for the measurement of glucose. The tubes were kept at low temperature and immediately centrifuged at $3500 \mathrm{rpm}$ for $10 \mathrm{~min}$ at $4^{\circ} \mathrm{C}$. The serum was stored frozen at $-70^{\circ} \mathrm{C}$ in sterile Eppendorf tubes until the time of analysis. Sandwich ELISA kits (Millipore) were used for hormone measurements.

The results were analyzed using the Statistica 10.0 and GraphPad Prism 6 programs. All variables were submitted to descriptive analysis consisting of the determination of the number of valid cases ( $n$ ), mean, median, minimum and maximum values, variance, and standard deviation. Application of the Kolmogorov-Smirnov normality test revealed that none of the variables showed a normal distribution. Therefore, the variables were analyzed using the nonparametric Friedman test and Dunn's post-test for multiple comparisons. All non-normally distributed variables are reported as the median (minimum and maximum). A p value $<0.05$ was considered to be significant.

\section{RESULTS}

Figures 1, 2 and 3 show the effect of the administration of palm oil on the parameters studied. There was a significant decrease in blood glucose levels from $112.4 \mathrm{mg} / \mathrm{dl}$ (79.1209) in the fasted state to $99.8 \mathrm{mg} / \mathrm{dl}$ (57.7-190.9) $2 \mathrm{~h}$ after the ingestion of palm oil $(p=0.018)$. A decrease in blood glucose levels was also observed $1 \mathrm{~h}$ after ingestion of the stimulus, from $112.4 \mathrm{mg} / \mathrm{dL}(79.1-209)$ to $102.8 \mathrm{mg} / \mathrm{dL}$ (70.5-193.4), but the difference was not significant $(p=0.09)$ (Figure 1).

A significant decrease in mean PYY levels was observed $2 \mathrm{~h}$ after the administration of palm oil, from $480 \mathrm{pg} / \mathrm{mL}$ (191-1000) to $310 \mathrm{pg} / \mathrm{mL}(140-740)(p=0.002)$. Comparison between the fasted state and $1 \mathrm{~h}$ after the administration of palm oil showed a decrease from $480 \mathrm{pg} / \mathrm{mL}$ (191-1000) to $360 \mathrm{pg} / \mathrm{mL}$ (191-870), but the difference was not significant $(p=0.15)$ (Figure 2).

Figure 3 illustrates the effect of the administration of palm oil on GLP-1 levels. The levels of this hormone decreased significantly from $8.6 \mathrm{pM}(3.1-100)$ in the fasted state to $8.4 \mathrm{pM}(3-45) 1 \mathrm{~h}$ after the administration of palm oil $(p=0.043)$. A slight decrease in GLP-1 levels was observed between $1 \mathrm{~h}$ and $2 \mathrm{~h}$ after administration of the stimulus, from $8.4 \mathrm{pM}(3-45)$ to $6 \mathrm{pM}(3-100)$, but the difference was not significant $(p=0.72)$. 
EFFECT OF PALM OIL ADMINISTRATION

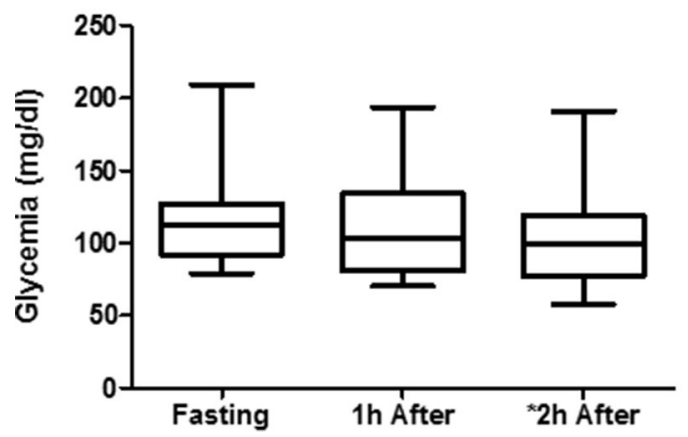

FIGURE 1 - Graph showing the median and minimum and maximum values of blood glucose levels in the fasted state and $1 \mathrm{~h}$ and $2 \mathrm{~h}$ after the administration of palm oil (nonparametric Friedman test) ${ }^{*} \mathrm{p}=0.018$

EFFECT OF PALM OIL ADMINISTRATION

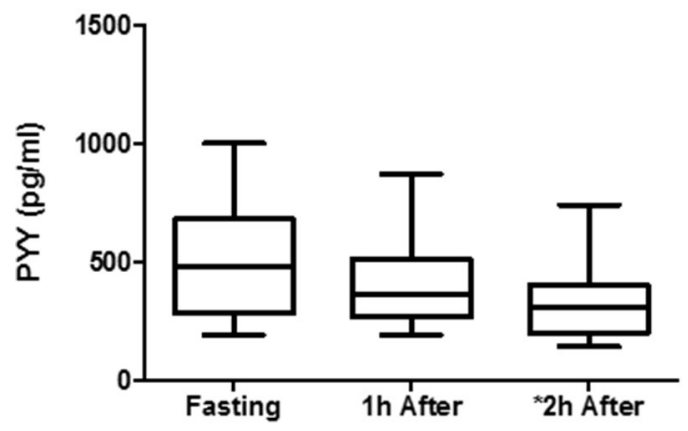

FIGURE 2 - Graph showing the median and minimum and maximum values of PYY concentration in the fasted state and $1 \mathrm{~h}$ and $2 \mathrm{~h}$ after the administration of palm oil (nonparametric Friedman test) ${ }^{*} p=0.0002$

\section{EFFECT OF PALM OIL ADMINISTRATION}

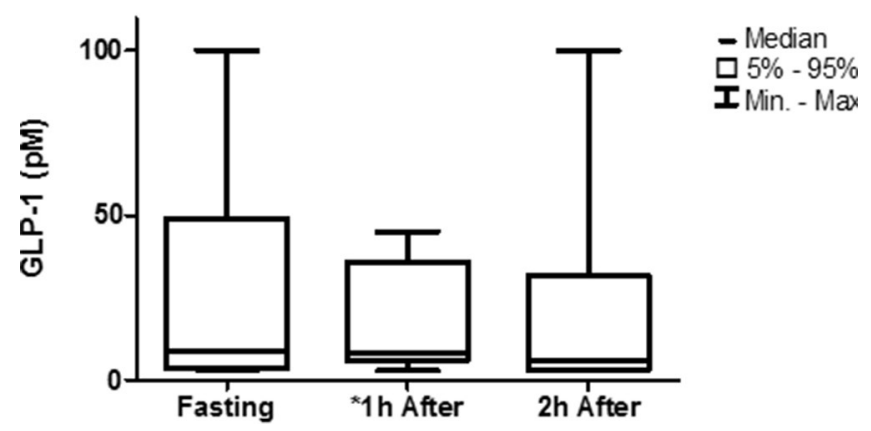

FIGURE 3 - Graph showing the median and minimum and maximum values of GLP-1 concentration in the fasted state and $1 \mathrm{~h}$ and $2 \mathrm{~h}$ after the administration of palm oil (nonparametric Friedman test) ${ }^{*} p=0.04$

Figures 4, 5 and 6 show the effect of the administration of glutamine on the studied parameters. Blood glucose levels decreased from $148.6 \mathrm{mg} / \mathrm{dL}$ (118.7-359.4) in the fasted state to $133.5 \mathrm{mg} / \mathrm{dL}$ (76.7-364) $2 \mathrm{~h}$ after the ingestion of the stimulus $(p=0.03)$. There was a nonsignificant decrease in blood glucose levels $1 \mathrm{~h}$ after the administration of glutamine (fasted state: $148.6 \mathrm{mg} / \mathrm{dL}$ (118.7-359.4), 1 h: $153.7 \mathrm{mg} / \mathrm{dL}$ (105.6-375.4); $p=0.25$ ) (Figure 4).

PYY concentration increased from $310 \mathrm{pg} / \mathrm{mL}$ (191$480)$ in the fasted state to $445 \mathrm{pg} / \mathrm{mL}(210-480) 1 \mathrm{~h}$ after the administration of glutamine, but the difference was not significant $(p=0.06)$. The concentration of PYY $(380 \mathrm{pg} / \mathrm{mL}$ (220-710)) remained elevated $2 \mathrm{~h}$ after the administration of glutamine when compared to the fasted state, but was lower when compared to $1 \mathrm{~h}$ after the stimulus. However, these differences were not significant $(p=0.26)$ (Figure 5$)$.

GLP-1 concentration increased from 33.5 pM (3-70) in the fasted state to $46 \mathrm{pM}(33.5-90) 1 \mathrm{~h}$ after the administration of glutamine, but the difference was not significant $(p=0.32)$. No significant difference in GLP-1 concentration was observed between the fasted state (33.5 pM (3-70)) and $2 \mathrm{~h}$ after the administration of glutamine (33.5 pM (3-65.9)) $(p=0.87)$ (Figure 6).

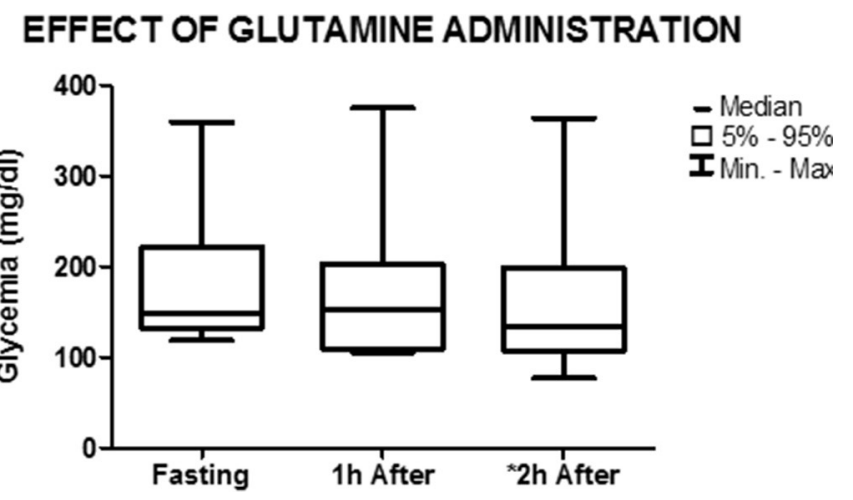

FIGURE 4 - Graph showing the median and minimum and maximum values of blood glucose levels in the fasted state and $1 \mathrm{~h}$ and $2 \mathrm{~h}$ after the administration of glutamine (nonparametric Friedman test) ${ }^{*} \mathrm{p}=0.03$

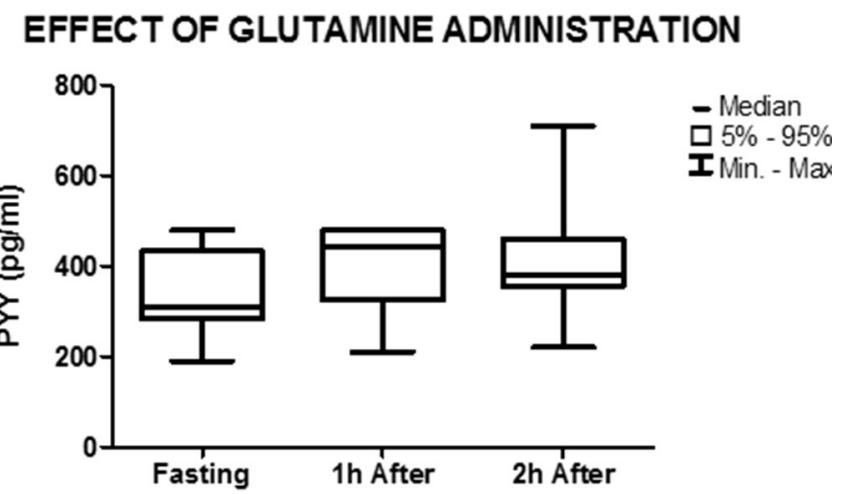

FIGURE 5 - Graph showing the median and minimum and maximum values of PYY in the fasted state and $1 \mathrm{~h}$ and $2 \mathrm{~h}$ after the administration of glutamine (nonparametric Friedman test) $p=0.06$

\section{EFFECT OF GLUTAMINE ADMINISTRATION}

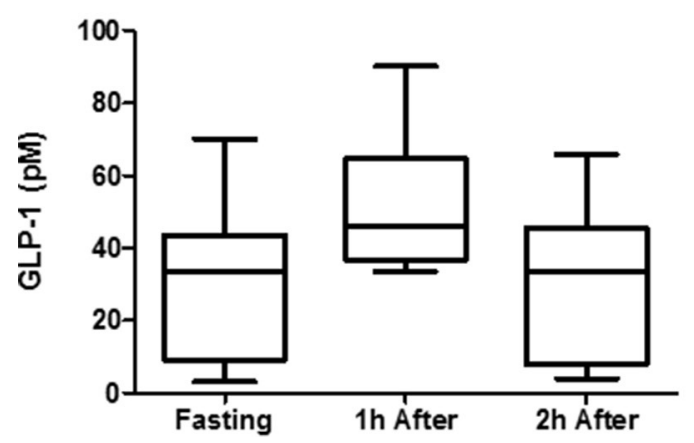

- Median ㅁ $5 \%-95 \%$ IMin. - Max

FIGURE 6 - Graph showing the median and minimum and maximum values of GLP-1 in the fasted state and $1 \mathrm{~h}$ and $2 \mathrm{~h}$ after the administration of glutamine (nonparametric Friedman test) $p=0.32$ 
DISCUSSION

The present study demonstrated a significant decline in blood glucose levels after ingestion of palm oil, suggesting that this compound can be used as an alternative for glycemic control in diabetic patients. Budin et al. ${ }^{3}$ treated streptozotocininduced diabetic rats with the tocotrienol-rich fraction of palm oil and observed a significant reduction of serum glucose and glycated hemoglobin in treated rats ${ }^{14}$.

On the other hand, Sundram et al. ${ }^{27}$ administered palm oil and other oleic compounds to 30 patients for four weeks and found no significant effect of palm oil on glucose concentration. The divergence between the results of the present study and those reported by Sundram et al. ${ }^{27}$ might be explained by the fact that the patients studied here were submitted to duodenojejunal bypass with ileal interposition and without gastrectomy, a condition that permits food to reach L-cells of the ileum more rapidly, exerting a hypoglycemic effect, or by physiological differences between humans and rats ${ }^{3,14}$

In the study of Robertson et al ${ }^{17}$, healthy women consumed a fraction of palm oil containing other saturated fatty acids as part of their meal. Measurement of serum GLP-1 and PYY levels showed hormone peaks 30 min after ingestion of the meal. In the present study, a significant decrease in PYY was observed $2 \mathrm{~h}$ after the ingestion of palm oil. These results suggest that the peak in this peptide occurs immediately after administration of the oil ${ }^{17}$.

Wit et al. ${ }^{30}$ fed C57BL/6J mice (genetically modified to develop obesity) a high-fat and low-fat diet. The two diets had the same composition of proteins, carbohydrates and fats, but differed in the proportion of individual fatty acids. The low-fat diet contained $20 \mathrm{~g}$ palm oil and the high-fat diet contained $177.5 \mathrm{~g}$ palm oil, in addition to soybean oil. The animals were fed the diet for 2, 4 and 8 weeks. The authors suggested that the high-fat diet does not influence incretins such as GLP-1 to an extent that would cause alterations in the insulin response pattern. Despite the observation of similar GLP-1 levels, comparison with the present study is limited since the diet administered by Wit et al. ${ }^{30}$ contained different compounds that could influence the mechanism of incretin action. In the present study, palm oil was administered to patients previously submitted to duodenojejunal bypass with ileal interposition and without gastrectomy and these factors cited may behave differently depending on the organism ${ }^{30}$.

There are some factors that may explain the significant reduction in GLP-1 after the administration of palm oil, such as the route of administration. The palm oil emulsion was encapsulated to facilitate its ingestion and therefore may have not been intact when it reached the portion of the ileum located immediately after the stomach in operated patients. Another factor related to the reduction in GLP-1 is the higher concentration of the hormone seen in fasted patients, suggesting that the surgical procedure had increased the secretion of this incretin in the fasted state

The effect of glutamine on the three parameters evaluated agrees with the results of studies reported in the literature. A mild increase in GLP-1 was observed in the first hour after the administration of glutamine $(p=0.32)$. Greenfield et al. ${ }^{9}$ and Tolhurst et al. ${ }^{29}$ showed that glutamine significantly increases the expression of GLP-1. The lack of a significant difference in the expression of GLP-1 observed in the present study might be due to the small number of patients. Another explanation are the high serum levels of GLP-1 seen in fasted patients, which were 33.5 pM (3-70), when compared to fasting plasma concentrations of this incretin of 2 to $15 \mathrm{pM}$ reported in the literature ${ }^{13}$. These elevated GLP-1 levels may be a consequence of surgery since, according to Rubino et al. ${ }^{22}$, duodenal bypass can interfere with the anti-incretin effect ${ }^{22}$.
In the study of Breitman et al. ${ }^{2}$, obese patients submitted to gastric bypass received $24 \mathrm{~g}$ of an oral supplement containing glutamine, leucine and arginine twice daily for eight weeks. The results showed that administration of the supplement caused a significant decrease in glucose over the period studied, even in non-diabetic patients. Insulin resistance improved despite the lack of a significant increase in GLP-1. The study of Breitman et al. ${ }^{2}$ shows some similarities with the procedures used in the present investigation. However, the surgical procedure adopted by these authors, gastric bypass, differs from that used here. In addition, the supplement administered by the authors was a combination of amino acids, whereas the present patients received only glutamine. It can be suggested that glutamine caused a decrease in glucose levels in the study of Breitman et al. ${ }^{2}$ or that other compounds have influenced the action of incretins.

The concentration of PYY increased in the first hour after the administration of glutamine, although the difference was not significant. This finding agrees with Reimann et al. ${ }^{16}$ who observed a significant increase in PYY after the administration of glutamine to rats submitted to resection of the small intestine. The lack of a significant increase in PYY might be due to the small number of patients studied.

In the present study, a significant decrease in blood glucose was observed $2 \mathrm{~h}$ after the ingestion of glutamine. Similar results have been reported by Samocha-Bonet et al. ${ }^{23}$ who found a significant reduction of glycemia in diabetic patients ingesting $30 \mathrm{~g}$ glutamine. Taken together, these results suggest that glutamine is a promising compound for short-term glycemic control.

GLP-1 was found to be increased in the fasted state. This finding suggests that surgery may have influenced the increase in this incretin. In this respect, Nauck et al..$^{12}$ demonstrated an effect of deterioration of incretins in patients with T2DM. The authors reported that the plasma alterations seen after oral administration of glucose were the same as those observed when glucose was administered intravenously. These results indicate that this incretin does not act completely on glycemic control. Another fact that may suggest that surgery exerted an effect on GLP-1 concentration is the finding of Toft-Nielsen et al. ${ }^{28}$ who observed impaired secretion of GLP-1 in patients with T2DM characterized by a significant decrease in the response of this incretin. Similar results have been reported by Chacra ${ }^{4}$.

Cohen et $a l .{ }^{5}$, studying 86 patients with a BMI of 22 to $34 \mathrm{~kg} / \mathrm{m}^{2}$ submitted to duodenojejunal bypass, observed long-term remission of T2DM in $78 \%$ of the patients, but no significant increase in GLP-1. These results suggest that the surgical procedure performed in the present study promotes intestinal alterations that differ from those induced by duodenojejunal bypass, increasing fasting GLP-1 concentration and thus contributing to the improvement of T2DM. In contrast, no ileal interposition is performed in duodenojejunal bypass. As a consequence, stimuli do not pass through L-cells and no increase in GLP-1 occurs.

\section{CONCLUSION}

The present results suggest that palm oil and glutamine influence intestinal peptides and glycemia.

\section{REFERENCES}

1. Bandeira F, Graf H, Griz L, Faria M, Lazaretti-Castro M. Endocrinologia e Diabetes. 2ed. Rio de Janeiro: MEDBOOK, 2009.

2. Breitman I, Saraf N, Kakade M, Yellumahanthi K, White M, Hackett JA, Clements RH. The Effects of an Amino Acid Supplement on Glucose Homeostasis, Inflammatory Markers, and Incretins after Laparoscopic Gastric Bypass. J Am Coll Surg. . 2011 Abr; 212(4): 617-627. 
3. Budin SB, Othman F, Louis SR, Bakar Ma, Das S, Mohamed J. The effects of palm oil tocotrienol-rich fraction supplementation on biochemical parameters, oxidative stress and the vascular wall of streptozotocin-induced diabetic rats. CLINICS. 2009; 64(3): 235-244

4. Chacra AR. Efeito Fisiológico Das Incretinas. Adv Stud Med. 2006; 6(7B): S613-S617.

5. Cohen R, Torres M, Schiavon C. Cirurgia metabólica: mudanças na anatomia gastrointestinal e a remissão do diabetes mellitus tipo 2. ABCD Arq Bras Cir. Dig. 2010; 23 (1): 40-45.

6. Cruzat VF, Petry ÉR, Tirapegui JO. Glutamina: aspectos bioquímicos, metabólicos, moleculares e suplementação. Rev Bras Med Esporte. 2009; 15: 392-397.

7. Diepvens K, Soenen S, Steijns J, Arnold M, Westerterp-Plantenga M. Long-term effects on consumption of a novel fat emulsion in relation to body-weight management. Int J Obes (Lond) 2007; 31: 942-949

8. Drucker DJ. The role of gut hormones in glucose homeostasis. J. Clin. Invest. 2007 jan; 117: 24-32.

9. Greenfield JR, Farooqi IS, Keogh JM, Henning E, Habib AM, Blackwood A, Reimann F, Holst JJ, Gribble FM. Oral glutamine increases circulating glucagon-like peptide 1, glucagon, and insulin concentrations in lean, obese, and type 2 diabetic subjects. Am J Clin Nutr. 2009; 89:106-113.

10. Grenier E, Garofalo C, Delvin E, Levy E. Modulatory Role of PYY in Transport and Metabolism of Cholesterol in Intestinal Epithelial Cells. Plos One. 2012 jul; 7(7).

11. Kashyap SR, Gatmaitan P, Brethauer S, Schauer P. Bariatric surgery for type 2 diabetes: Weighing the impact for obese patients. Cleve Clin J Med. 2010 Jul; 77(7): 468-476.

12. Nauck MA, Vardarli I, Deacon CF, Holst JJ, Meier JJ. Secretion of glucagon-like pepetide-1 (GLP-1) in type 2 diabetes: what is up, what is down? Diabetologia. 2011 set; 54(10), 10-18.

13. Peruzzo GM. Análise dos Níveis de GLP-1 nos Estados de Jejum e Pós prandial Durante a Gestação em Mulheres Não Diabéticas. [dissertação] [internet] Programa de Pós graduação em Saúde e Desenvolvimento na Região Centro-oeste, Universidade Federal de Mato Grosso do Sul, Campo Grande. 2010 [Acesso em 24 de novembro de 2011]. Disponível em <http://www.cbc.ufms.br/ tedesimplificado/tde_arquivos/14/TDE-2010-12-13T115508Z-636/ Publico/Giselle.pdf>

14. Pories WJ, Albrecht RJ. Etiology of type 2 diabetes mellitus: role of the foregut. World J Surg. 2001;25: 527-531.

15. Reimann F. Molecular mechanisms underlying nutrient detection by incretin-secreting cells. Int Dairy J. 2010; 20: 236-242.

16. Reimann, F., Williams, L., da Silva Xavier, G., Rutter, G.A. and Gribble, F.M. Diabetologia. 2004; 47: 1592-1601

17. Robertson M, Jackson K, Fielding B, Morgan L, Williams C, Frayn K. Acute ingestion of a meal rich in $n-3$ polyunsaturated fatty acids results in rapid gastric emptying in humans. Am J Clin Nutr 2002; 76: 232-238.
18. Rocha H, Carvalho R. O papel das incretinas no tratamento da Diabetes Mellitus tipo 2. [dissertação] [internet]. Instituto de Ciências Biomédicas Abel Salazar, Universidade do Porto, Porto, 2009. [acesso em 28 de julho de 2011]. Disponível em http://repositorio-aberto. up.pt/bitstream/10216/21023/2/tese\%20final.pdf.

19. Ross SA, Ekoé JM. Incretin agents in type 2 diabetes. Can Fam Physician. 2010; 56: 639-648

20. Roux CW, Aylwin SJB, Batterham RL, Borg CM, Coyle F, Prasad V, Shurey S, Ghatei MA, Patel AG, Bloom SR. Gut Hormone Profiles Following Bariatric Surgery Favor an Anorectic State, Faciliate Weight Loss, and Improve Metabolic Parameters. Ann Surg. 2006; 243: 108-114.

21. Rubino F, Gagner M. Potencial of Surgery for Curing Type 2 Diabtes Mellitus. Ann Surg. 2002 Nov; 236(5): 554-559.

22. Rubino F, R'bibo SL, Genio F, Mazumdar M, Mcgraw TE. Metabolic surgery: the role of the gastrointestinal tract in diabetes mellitus. Nat Rev Endocrinol. 2010 Fev; 6(2): 102-109.

23. Samocha-Bonet D, Wong O, Synnott EL, Piyaratna N, Douglas A, Gribble FM, Holst JJ, Chisholm DJ, Greenfield JR. Glutamine reduces postprandial glycemia and augments the glucagon-like peptide-1 response in type 2 diabetes patients. J Nutr. 2011;141:1233-8.

24. Sen CK, Rink C, Khanna S. Palm Oil-Derived Natural Vitamin E $\alpha$-Tocotrienol in Brain Health and Disease. J Am Coll Nutr. 2010 Jun; 29(3 Suppl): 314S-323S.

25. Shimizu H, Tinratana P, Shauer PR, Rogula T. Review of Metabolic Surgery for Type 2 Diabetes in Patients with a BMI < 35 kg/m2. Journal of Obesity. 2012 mar; 2012.

26. Silva AD. Bloom SR. Gut Hormones and Appetite Control: A Focus on PYY and GLP-1 as Therapeutic Targets in Obesity. Gut Liver. 2012; 6: $10-20$.

27. Sundram K, Karupaiah T, Hayes KC. Stearic acid-rich interesterified fat and trans-rich fat raise the LDL/HDL ratio and plasma glucose relative to palm olein in humans. Nutr Metab 2007;4:3

28. Toft-Nielsen MB, Damholt MB, Madsbad S, et al. Determinants of the impaired secretion of glucagon-like peptide- 1 in type 2 diabetic patients. J Clin Endocrinol Metab 2001; 86: 3717-23.

29. Tolhurst G, Zheng Y, Parker HE, Habib AM, Reimann F, Gribble FM. Glutamine triggers and potentiates glucagon-like peptide-1 secretion by raising cytosolic $\mathrm{Ca} 2+$ and cAMP. Endocrinology. 2011;152:405-13.

30. Wit NJ, Bosch-Vermeulen $\mathrm{H}$, de Groot PJ, et al. The role of the small intestine in the development of dietary fat-induced obesity and insulin resistance in C57BL/6J mice. BMC Med Genomics 2008;1:14. 
In the article "EFFECT OF PALMA AND GLUTAMINE OIL IN THE SERIES LEVELS OF GLP-1, PYY AND GLYCEMIA IN CARRIERS OF DIABETE MELITO TYPE 2 SUBMITTED TO METABOLIC SURGERY", with the number of DOI: /10.1590/S0102-6720201400S100013 published no. Journal of the Brazilian Archives of Digestive Surgery, 27 (Suppl 1): 51-55, on page 51:

Where it read:

Financial source: none

Read:

Financial source: Foundation for Research Support of the State of Minas Gerais

(FAPEMIG) 